Sri Lankan J. Biol. 2022, 7 (1): 12 - 17

DOI: http://doi.org/10.4038/sljb.v7i1.79

https://orcid.org/0000-0002-0459-0621

Research Article

Open Access

\title{
Isolation of gut associated bacteria from Callinectes amnicola (Crustacea: Portunidae) collected from two interconnecting tropical lagoons in Nigeria
}

Moruf, R.O.*

Department of Fisheries and Aquaculture, Faculty of Agriculture, Bayero University, Kano, Nigeria.

\begin{abstract}
The occurrence and relative distribution of bacterial flora associated with the gut of the crab Callinectes amnicola, as well as sediment and water, from Badagry and Epe Lagoons, were investigated. The water samples from the Epe Lagoon had the highest total bacteria count of $7.5 \pm 1.2 \times 10^{7} \mathrm{cfug}_{-}{ }^{1}$, whereas the crab gut from the Badagry Lagoon had the lowest total bacteria count of $3.6 \pm 0.5 \times 10^{7}$ cfug- $^{1}$. The analyzed plate counts from the gut of $C$. amnicola, included the total heterotrophic bacteria, total coliform and total faecal coliform which were greater in the Epe Lagoon than in the Badagry Lagoon although these differences were not significant $(p>0.05)$. The values recorded for the Epe Laggon were $4.5 \pm 0.2 \times 10^{7}$ cfug- ${ }^{1}, 3.4 \pm 0.1 \times 10^{5} \mathrm{cfug}_{-}{ }^{1}$ and $1.5 \pm 0.3 \times 10^{5} \mathrm{cfug}_{-}{ }^{1}$ for total heterotrophic bacteria, total coliform and total faecal coliform respectively. All the nine (9) identified isolates, with the exception of Streptococcus sp, were largely gram-negative bacteria, and included Escherichia coli, Salmonella typhi, Shigella sp., Proteus vulgaris, Pseudomonas aeruginosa, Bacillus sp., Aeromonas hydrophila and Vibrio cholera. Except for Shigella sp., which was absent in the Badagry Lagoon during the study period, the isolates found in this study were comparable in both locations. The most common isolates in the gut of $C$. amnicola obtained from the two interconnected lagoons were A. hydrophila and E. coli. This study is useful for authorities to develop coastal contamination monitoring strategies and quantify the human health risks connected with the consumption of aquatic crabs.
\end{abstract}

Received: 16 June 2021

Accepted: 18 August 2021

Key words:

Bacteria

Badagry Lagoon

Crab

Epe Lagoon

Pathogen

*Corresponding author: tunjimoruf@gmail.com

\section{Introduction}

Coastal lagoons serve as nursery and feeding areas for many continental and marine species. In tropical lagoons, Callinectes species predominate, accounting for the majority of landed crabs. The Lagoon Crab (Callinectes amnicola), belonging to the Portunidae is a decapod crustacean of high commercial value in Nigeria (Moruf \& Lawal-Are, 2017a). In human and animal diets, the species is commonly considered as a valuable source of protein and minerals (Chindah et al., 2000; Moruf et al., 2019), as well as the most important food organism collected in West African coastal (inshore) fisheries and lagoons (Lawal-Are \& Kusemiju, 2000; Moruf \& Adekoya, 2020).

Food safety has recently become a catchphrase, thanks to rising consumer knowledge of ill effects of consuming substandard food and the role of independent media as ombudsmen (Geetha et al., 2016). Crabs and shrimps have been implicated in Vibrio parahaemolyticus food poisoning, cholera, salmonellosis, shigellosis and Yersinia food infection (Uaboi-Egbenni et al., 2010). Furthermore, bacterial diseases are the second major cause of mortality in both wild and cultured crabs, while the major cause being viral infections. The actual role of these microorganisms may vary from that of a primary pathogen to that of an opportunist invader of a host rendered moribund by some other diseases 
process (Akintola et al., 2009). Opportunistic pathogens are organisms that usually do not cause disease unless the host's immune system is compromised.

It has been shown by research that the microfauna of aquatic animals is highly variable and reflects the individual animal's surroundings, particularly the food they eat while a majority of these bacterial flora are carried in the gastrointestinal tract (Akintola et al., 2009). Previous work on C. amnicola focused on its distribution (Abowei \& George, 2010), diet ecology (Moruf \& Lawal-Are, 2017b) and reproductive biology (Lawal-Are, 2010). The significance of pathogenic bacteria in the Callinectes $s p$ from the Lagos Lagoon has been investigated (Uaboi-Egbenni et al., 2010), but little is known about $C$. amnicola gut bacterial flora in the country. Therefore, this work would provide baseline data on the occurrence and distribution of gastro-intestinal bacteria in wild stocks of $C$. amnicola from two important lagoon systems namely the Badagry and Epe Lagoons, in the Southwestern part of Nigeria.

\section{Materials and Methods}

\subsection{Study site}

The two study sites, the Badagry Lagoon $\left(6^{\circ} 25^{\prime} 415^{\prime \prime}\right.$ $\mathrm{N}$ and $\left.2^{\circ} 60^{\prime} 43^{\prime \prime} \mathrm{E}\right)$ and the Epe Lagoon (6 $6^{\circ} 29^{\prime} 6.38^{\prime \prime}$ $\mathrm{N}$ and $\left.3^{\circ} 35^{\prime} 4^{\circ} 40^{\prime \prime} \mathrm{E}\right)$ are located within Lagos State, South-West Nigeria (Figure 1). The two lagoons are part of a continuous system of lagoons and creeks along the coast of Nigeria. Six sampling stations were selected in each lagoon. Site selection was based on increasing anthropogenic effects, particularly from the discharge of domestic and solid waste.

\subsection{Collection of Samples}

The sampling was conducted between May and October 2019, where similar numbers of samples were collected from each station. A total of 120 fresh samples of $C$. amnicola collected live were transported to the laboratory and weighed sartorius top loading balance (Model 1106) to the nearest tenth of a gram. Specimens in the weight range of $178-226 \mathrm{~g}$ and 116 - $204 \mathrm{~g}$, from Badagry Lagoon and Epe Lagoon respectively, were used for the study. The surface water temperature was measured by dipping the glass (bulb) of the thermometer (HT09 in Coimbatore, Tamil Nadu) into the water, $15 \mathrm{~cm}$ below the water surface and allowed to stand for 2 minutes before taking the reading between the hours of 16-8 am. The $\mathrm{pH}$ was measured in the field using an Oakton pH Meter (Model 35624-00, Cerritos, California). Six representative samples of bottom sediment (to a depth of $2 \mathrm{~cm}$ ) were collected from each station using a Veen Grab (wt. $25 \mathrm{~kg}$; height $-20 \mathrm{~cm}, \mathrm{~m}$ ) following the procedure of dos Santos et al. (2000).

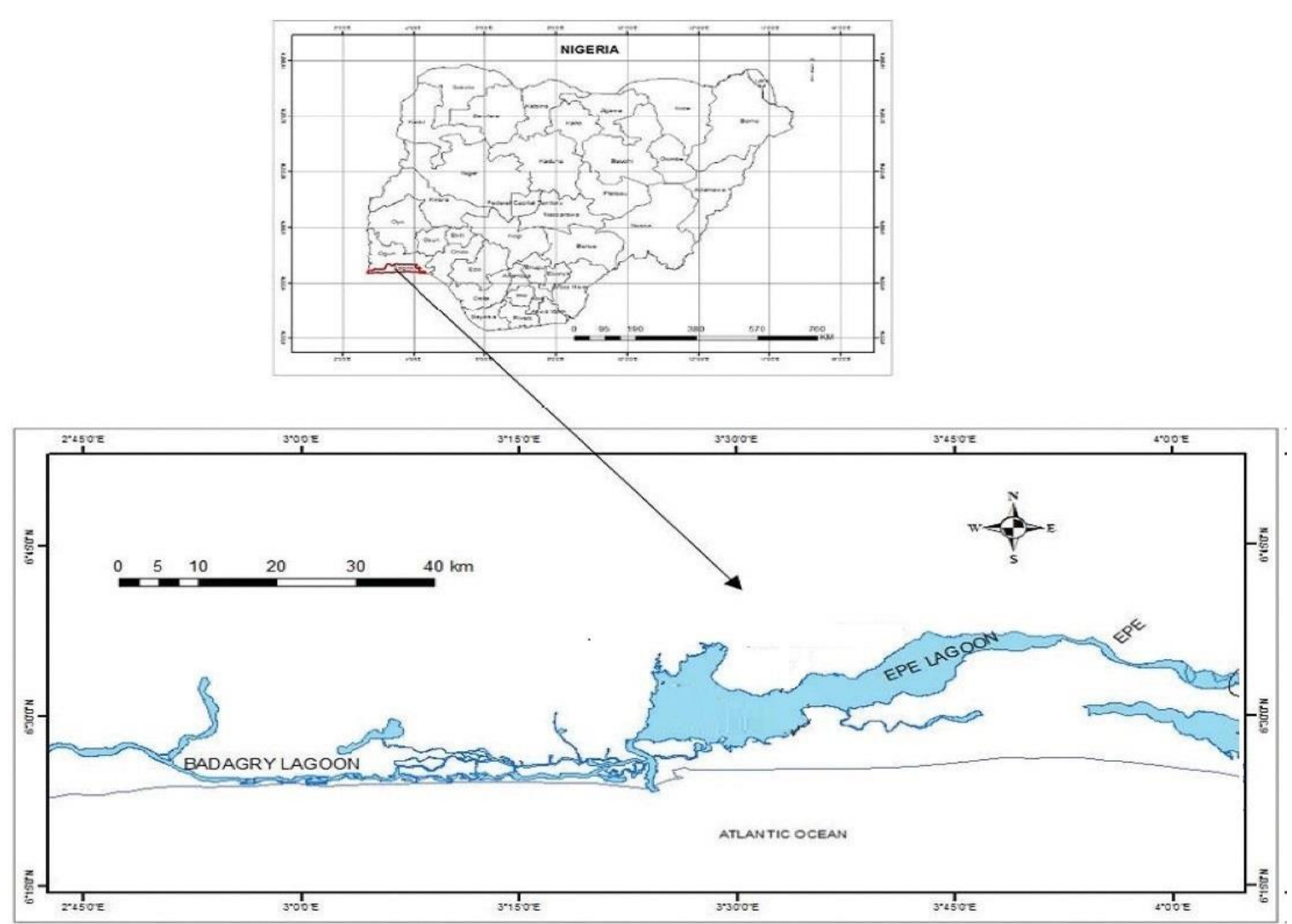

Fig 1. Map of Badagry and Epe Lagoons (adapted from Akinwunmi \& Moruf, 2021) 


\subsection{Preparation of Samples}

Twenty randomly chosen specimens from each lagoon were sacrificed and the number of incidental organisms was removed by washing their skin with $70 \%$ ethanol before opening the ventral surface with sterile scissors to expose the gut. Five grams of each crab gut sample was mixed with $225 \mathrm{~mL}$ of sterile $(0.1 \%)$ peptone water in a sterile beaker and thoroughly homogenized under aseptic conditions. Thereafter, the homogenized samples were serially diluted to $10^{6}$ as described by the American Public Health Association (2001).

\subsection{Isolation and Characterization of Isolates}

Gram's staining procedure and the method for ascertaining motility followed Harrigan \& McCance (1976). The method for determining fecal contamination indicators is the fermentation in multiple tubes method, which is based on seeding a series of three tubes with liquid media, then determining the number of positive tubes by referring to table of three probability tubes set out in Mc Grady (Hamiroune et al., 2020). The most probable number technique was employed in the microbial examination of water and sediment with different agar to identify each target organism using the pour plate method (Saxena et al., 2015).

Biochemical tests were done according to tests and descriptions of Collins \& Lyne (1984). Further identification of bacterial isolates into species was done according to tests and descriptions in the
Bergey's manual of Systemic bacteriology (Krieg \& Holt, 1984).

\subsection{Statistical Analysis}

Data were analyzed using the descriptive statistic SPSS (version 20). Differences in means were tested using $\mathrm{t}$-test with the significance level being set at $\mathrm{P}<0.05$.

\section{Results}

The water quality condition of the crab collection sites are given in Table 1. The highest mean temperature of 31.8 $\pm 2.8 \mathrm{C}$ (range $=29-34.6 \mathrm{C}$ ) was recorded in the Badagry Lagoon in May while the lowest mean temperature of $23.1 \pm 1.3 \mathrm{C}$ (range= 21.8-24.4 C) was recorded in the Epe Lagoon in September. Similarly, the highest $\mathrm{pH}$ mean value of $7.9 \pm 0.5$ (7.9-8.9) was recorded in the Badagry Lagoon in October while the lowest mean value of 6.1 \pm 0.7 (5.4-6.8) was recorded in the Epe Lagoon in May (Table 1).

Table 2 depicts the mean total bacteria counts in water, sediment and gut samples of $C$. amnicola from the Badagry and Epe lagoons. The highest total bacteria count of $7.5 \pm 1.2 \times 10^{7} \mathrm{cfug}$ was seen in water samples from Epe Lagoon while the least value of $3.6 \pm 0.5 \times 10^{7} \mathrm{cfug}$ was obtained in the crab gut from Badagry Lagoon. Significant difference $(\mathrm{P}<0.05)$ was only observed between the bacterial counts of the two lagoons (Badagry Lagoon, $5,7 \pm 0.5$ x $10^{7} \mathrm{cfug}^{-1}$; Epe Lagoon, $7.5 \pm 1.2 \times 10^{7} \mathrm{cfug}^{-1}$ ).

Table 1. Mean \pm standard error values of temperature and $\mathrm{pH}$ in two interconnecting lagoons, Nigeria

\begin{tabular}{lcccc}
\hline \multirow{2}{*}{ Month } & \multicolumn{2}{c}{ Temperature $\left({ }^{\circ} \mathrm{C}\right)$} & \multicolumn{2}{c}{$\mathrm{pH}$} \\
& Badagry Lagoon & Epe Lagoon & Badagry Lagoon & Epe Lagoon \\
\hline May & $31.8 \pm 2.8(29-34.6)$ & $31.1 \pm 2.3(28.8-33.3)$ & $7.6 \pm 0.3(7.3-7.9)$ & $6.1 \pm 0.7(5.4-6.8)$ \\
June & $26 \pm 3.3(22.7-29.3)$ & $29.1 \pm 0.2(28.9-29.3)$ & $7.2 \pm 0.7(6.5-7.8)$ & $6.7 \pm 0.9(5.8-7.6)$ \\
July & $24.6 \pm 1.1(23.5-25.7)$ & $29.2 \pm 0.65(28.5-29.8)$ & $6.8 \pm 0.9(5.9-7.6)$ & $7.4 \pm 0.1(7.3-7.5)$ \\
August & $25.45 \pm 3.5(22.0-28.9)$ & $28.2 \pm 1.4(26.8-29.6)$ & $6.9 \pm 0.1(6.8-7.0)$ & $6.2 \pm 0.3(5.9-6.5)$ \\
September & $28.6 \pm 0.7(27.9-29.3)$ & $23.1 \pm 1.3(21.8-24.4)$ & $6.9 \pm 0.3(6.6-7.1)$ & $7.0 \pm 0.4(6.6-7.4)$ \\
October & $26.2 \pm 0.3(25.9-26.5)$ & $27.5 \pm 0.6(26.9-28.1)$ & $7.9 \pm 0.5(7.9-8.9)$ & $6.9 \pm 0.1(6.8-7.0)$ \\
\hline
\end{tabular}

Values are not significantly different between sites $(\mathrm{p}>0.05)$

Table 2. Mean \pm standard values of the total bacterial counts ( $\mathrm{cfug}^{-1}$ ) in water, sediment and the guts of Callinectes amnicola from two interconnecting tropical lagoons in Nigeria.

\begin{tabular}{lccc}
\hline Component & Badagry Lagoon & Epe Lagoon & $p$-value (t-test) \\
\hline Crab gut & $3.6 \pm 0.5 \times 10^{7}$ & $4.5 \pm 0.2 \times 10^{7}$ & 0.4 \\
Water & $5.7 \pm 0.5 \times 10^{7}$ & $7.5 \pm 1.2 \times 10^{7}$ & $0.0^{*}$ \\
Sediment & $4.5 \pm 0.2 \times 10^{7}$ & $6.7 \pm 0.5 \times 10^{7}$ & 0.1 \\
\hline
\end{tabular}

*: Significantly different at $\mathrm{p}<0.05$

Bacterial loads in the guts of Callinectes amnicola from the Badagry and Epe lagoons are shown in Table 3. Morphological and biochemical characterization of cells found in the gut of $C$. amnicola from the two lagoons indicated that a total nine (9) bacterial species were present (Table 4).
With the exception of Streptococcus sp, all the characterized cells were predominantly gramnegative bacteria. 
Table 3. Mean \pm standard error values of bacterial loads $\left(\mathrm{cfu}^{-1}\right)$ in the guts of Callinectes amnicola from two interconnecting tropical lagoons in Nigeria.

\begin{tabular}{lccc}
\hline Plant Count & Badagry Lagoon & Epe Lagoon & $p$-value (t-test) \\
\hline Total heterotrophic bacteria & $3.6 \pm 0.5 \times 10^{7}$ & $4.5 \pm 0.2 \times 10^{7}$ & 0.1 \\
Total coliform counts & $2.7 \pm 0.3 \times 10^{5}$ & $3.4 \pm 0.1 \times 10^{5}$ & 0.2 \\
Total fecal Coliform & $1.2 \pm 0.2 \times 10^{5}$ & $1.5 \pm 0.3 \times 10^{5}$ & 0.5 \\
\hline
\end{tabular}

Values are not significantly different between sites ( $\mathrm{p}>0.05)$

Table 4. Morphological and biochemical characteristics of bacterial isolates from the gut of Callinectes amnicola from Badgary and Epe lagoons in Nigeria.

\begin{tabular}{lcccccccccc}
\hline \multirow{2}{*}{ Parameter } & \multicolumn{9}{c}{ Probable organism } & \multicolumn{3}{c}{} \\
\hline Shape & $\mathrm{a}$ & $\mathrm{b}$ & $\mathrm{c}$ & $\mathrm{d}$ & $\mathrm{e}$ & $\mathrm{f}$ & $\mathrm{g}$ & $\mathrm{h}$ & $\mathrm{I}$ \\
Gram reaction & Rod & Rod & Rod & Rod & Rod & Rod & Rod & Comma & Cocci \\
Catalase test & - & - & - & - & - & - & - & - & + \\
Motility & + & + & - & - & + & + & + & + & - \\
Urease & + & + & - & + & + & + & + & + & - \\
Oxidase & - & - & - & + & - & - & - & - & - \\
Citrate test & - & - & - & - & + & + & - & + & - \\
indole & - & - & - & + & + & - & - & + & + \\
mannitol & + & + & - & - & - & + & + & + & - \\
Glucose & + & + & - & - & + & - & + & + & + \\
Sucrose & + & + & + & + & + & + & + & + & + \\
Lactose & + & + & - & + & + & + & + & + & + \\
\hline
\end{tabular}

a: Escherichia coli; b: Salmonella typhi; c: Shigella sp.; d: Proteus vulgaris;e: Pseudomonas aeruginosa; f: Bacillus sp.; g: Aeromonas hydrophila; h: Vibrio cholerae; i: Streptococcus sp.

The gram-negative bacteria species found commonly in the gut of $C$. amnicola were Escherichia coli, Salmonella typhi, Shigella sp., Proteus vulgaris, Pseudomonas aeruginosa, Bacillus sp., Aeromonas hydrophila and Vibrio cholera. The relative distribution of isolates from Badagry Lagoon showed that Aeromonas hydrophila was the highest in the gut of $C$. amnicola in May, June, September and October, accounting for $28.75 \%(\mathrm{n}=23), 33.33 \%(\mathrm{n}=19), 25.81 \%(\mathrm{n}=16)$ and $27.78 \%(\mathrm{n}=20)$ respectively (Table 5). Shigella $s p$. was not recorded from crabs from the Badagry Lagoon.

In the Epe Lagoon, all the identified isolates were present in the gut of $C$. amnicola throughout the period of study (Table 6). The highest distribution of bacterial isolates $(23.58 \%)$ was found to be of Escherichia coli in August, followed by $A$. hydrophila representing $21.21 \%$ of the isolates in May. With the exception of May and June, E. coli was predominant throughout the months of the study.

\section{Discussion}

The water quality of the sites from where crabs were collected during the present study showed optimum conditions for this species. The mean temperature range was $25-32^{\circ} \mathrm{C}$ whereas the $\mathrm{pH}$ range was $7.5-$ 8.5 which were similar to the conditions required for the production of portunid crabs (Ikhwanuddin, 2020).

Table 5. Monthly percentage distribution of isolates in the gut of Callinectes amnicola from the Badagry Lagoon

\begin{tabular}{|c|c|c|c|c|c|c|c|c|c|c|c|c|}
\hline \multirow{2}{*}{ Bacteria } & \multicolumn{2}{|c|}{ May } & \multicolumn{2}{|c|}{ June } & \multicolumn{2}{|c|}{ July } & \multicolumn{2}{|c|}{ August } & \multicolumn{2}{|c|}{ September } & \multicolumn{2}{|c|}{ October } \\
\hline & $\mathrm{N}$ & $\%$ & $\mathrm{~N}$ & $\%$ & $\mathrm{~N}$ & $\%$ & $\mathrm{~N}$ & $\%$ & $\mathrm{~N}$ & $\%$ & $\mathrm{~N}$ & $\%$ \\
\hline Escherichia coli & 11 & 13.75 & 13 & 22.81 & 16 & 25.81 & 19 & 26.39 & 14 & 22.58 & 16 & 22.22 \\
\hline Salmonella typhi & 15 & 18.75 & 7 & 12.28 & 15 & 24.19 & 9 & 12.50 & 14 & 22.58 & 10 & 13.89 \\
\hline Shigella sp. & 0 & 0.00 & 0 & 0.00 & 0 & 0.00 & 0 & 0.00 & 0 & 0.00 & 0 & 0.00 \\
\hline Proteus vulgaris & 4 & 5.00 & 2 & 3.51 & 2 & 3.23 & 18 & 25.00 & 3 & 4.84 & 5 & 6.94 \\
\hline Pseudomonas aeruginosa & 5 & 6.25 & 11 & 19.30 & 8 & 12.90 & 0 & 0.00 & 3 & 4.84 & 9 & 12.50 \\
\hline Bacillus sp. & 0 & 0.00 & 2 & 3.51 & 5 & 8.06 & 4 & 5.56 & 1 & 1.61 & 5 & 6.94 \\
\hline Aeromonas hydrophila & 23 & 28.75 & 19 & 33.33 & 13 & 20.97 & 15 & 20.83 & 16 & 25.81 & 20 & 27.78 \\
\hline Vibrio cholerae & 18 & 22.50 & 0 & 0.00 & 0 & 0.00 & 5 & 6.94 & 7 & 11.29 & 5 & 6.94 \\
\hline Streptococcus feacalis & 4 & 5.00 & 3 & 5.26 & 3 & 4.84 & 2 & 2.78 & 4 & 6.45 & 2 & 2.78 \\
\hline
\end{tabular}


Table 6. Monthly percentages of isolates in the gut of Callinectes amnicola from the Epe Lagoon

\begin{tabular}{lcccccccccccc}
\hline \multirow{2}{*}{ Bacteria } & \multicolumn{2}{c}{ May } & \multicolumn{2}{c}{ June } & \multicolumn{3}{c}{ July } & \multicolumn{3}{c}{ August } & \multicolumn{3}{c}{ September } & \multicolumn{3}{c}{ October } \\
& $\mathrm{N}$ & $\%$ & $\mathrm{~N}$ & $\%$ & $\mathrm{~N}$ & $\%$ & $\mathrm{~N}$ & $\%$ & $\mathrm{~N}$ & $\%$ & $\mathrm{~N}$ & $\%$ \\
\hline Escherichia coli & 14 & 10.61 & 17 & 14.91 & 24 & 18.90 & 29 & 23.58 & 23 & 17.16 & 19 & 16.10 \\
Salmonella typhi & 23 & 17.42 & 19 & 16.67 & 13 & 10.24 & 15 & 12.20 & 17 & 12.69 & 19 & 16.10 \\
Shigella sp. & 9 & 6.82 & 0 & 0.00 & 0 & 0.00 & 2 & 1.63 & 4 & 2.99 & 2 & 1.69 \\
Proteus vulgaris & 15 & 11.36 & 13 & 11.40 & 21 & 16.54 & 11 & 8.94 & 17 & 12.69 & 13 & 11.02 \\
Pseudomonas aeruginosa & 4 & 3.03 & 9 & 7.89 & 18 & 14.17 & 17 & 13.82 & 14 & 10.45 & 10 & 8.47 \\
Bacillus sp. & 9 & 6.82 & 11 & 9.65 & 12 & 9.45 & 15 & 12.20 & 11 & 8.21 & 13 & 11.02 \\
Aeromonas hydrophila & 28 & 21.21 & 23 & 20.18 & 19 & 14.96 & 14 & 11.38 & 23 & 17.16 & 19 & 16.10 \\
Vibrio cholerae & 23 & 17.42 & 19 & 16.67 & 13 & 10.24 & 15 & 12.20 & 17 & 12.69 & 19 & 16.10 \\
Streptococcus feacalis & 7 & 5.30 & 3 & 2.63 & 7 & 5.51 & 5 & 4.07 & 8 & 5.97 & 4 & 3.39 \\
\hline
\end{tabular}

However, this condition is also known to be favourable for the proliferation of microorganisms as reported by Nayak (2010).

Even though shellfish, such as crabs are substantially nutritious and have become an increasingly significant source of inexpensive proteins and other essential nutrients, they harbour some pathogenic microorganisms which could be attributed to poor hygienic conditions of the water bodies from where they are obtained (Oranusi et al., 2018; Okon et al., 2020). Evidence indicates that the gastro- intestinal bacteria of aquatic organisms is highly variable and is a reflection of their environment (Nayak, 2010).

In the present study, the highest bacteria load was recorded in a water sample from the Epe Lagoon while the lowest was in the crab gut from the Badagry Lagoon. Significant difference was only observed in the bacterial counts in water samples from the two lagoons. Furthermore, the higher total heterotrophic bacteria, total coliform and total faecal coliform were recorded in the gut of $C$. amnicola from the Epe Lagoon. These high bacterial loads substantiated the results of Akintola et al. (2009), who reported a range of $5.7 \pm 0.3 \times 10^{7} \mathrm{cfu} \mathrm{g}^{-1}$ to 8.1 $\pm 0.3 \times 10^{7} \mathrm{cfu} \mathrm{g}^{-1}$ total viable counts in the gut of shellfish from the Epe Lagoon.

Moreover, a total of nine bacterial species were identified from the gut of $C$. amnicola. With the exception of Streptococcus sp, all the characterized cells were predominantly gram-negative bacteria, which included Escherichia coli, Salmonella typhi, Shigella sp., Proteus vulgaris;e, Pseudomonas aeruginosa, Bacillus sp., Aeromonas hydrophila and Vibrio cholera. The isolates obtained in this study were similar for both locations except that Shigella sp. was absent in the Badagry Lagoon throughout the study period. A. hydrophila and $E$. coli were the most dominant bacterial isolates in the gut of $C$. amnicola collected from the two lagoons. These results are similar to those obtained by UaboiEgbenni et al. (2010), where E. coli, Proteus vulgaris, Salmonella sp, Streptococcus agalactiae, Vibrio sp, and Staphylococcus aeureus were prevalent in Callinectes sp. obtained from the Lagos Lagoon in Nigeria. Reports have shown that the occurrence of both Salmonella typhi and Vibrio cholerae in the aquatic organism is evidence of high human interactions associated within the two lagoons (Akintola et al., 2009; Uaboi-Egbenni et al., 2010). In addition, the presence of coliform bacteria indicates previous contamination of the lagoon with raw sewage.

\section{Conclusions}

This study showed the presence of a consortium of pathogens in the gut of Callinectes amnicola, as well as sediment and water, from Badagry and Epe Lagoons in Nigeria. The high occurrence of these pathogenic bacterial species in the lagoons indicates high levels of untreated sewage and solid waste disposal into the lagoon environment and this calls for urgent intervention. This study is useful for authorities to develop coastal contamination monitoring strategies and for assessing human health risks connected with the consumption of aquatic crabs.

\section{Acknowledgement}

The author would like to thank Prof. (Mrs) Aderonke Omolara Lawal-Are, Department of Marine Sciences, University of Lagos, for the technical assistance provided in the study. The author would also like to acknowledge the editorial assistance rendered by Hajia Hawwau Moruf (CLN) of the Department of Library and Information Science, Federal University Dutsin-Ma, Katsina State, Nigeria.

\section{References}

Abowei, J.F.N., George, A.D.I. (2010) The morphology, abundance, size and sex distribution of Callinectes amnicola (De Rocheburne, 1883) from Okpoka Creek, Niger Delta, Nigeria. Current Research Journal Biological Science 2(1): 29-34.

Akintola, S.L., Bakare, S.B., Adewolu, M.A., Raheem, Q.A. (2009) Relative abundance and distribution of bacteria in the gut of 
Macrobrachium vollenhovenii from Badagry creek and Epe lagoon, Lagos state Nigeria. Zoologist (The) 7: 88-95.

Akinwunmi, M.F., Moruf, R.O. (2021) Aspects of the bionomics of Brackish Water Prawn (Macrobrachium macrobrachion: Herklots $1851)$ in the interconnecting lagoons of SouthWestern Nigeria. Egyptian Journal of Basic and Applied Sciences 8 (1): 222-234.

American Public Health Association (2001) Drinking water quality and public health (position paper). American journal of public health 91(3): 1-499.

Chindah, A.C., Tawari, C.C., Ifechukwude, K.A. (2000) The food and feeding habit of the blue crab Callinectes amnicola (Portunidae) of the new Calabar River, Nigeria. Journal of Applied Science and Environmental Management 4:5157.

Collins, C.H., Lyne, P.M. (1984) Microbiological methods 5th Edition. Butterworth\&co (Puplishers) Ltd, United kingdom. 137-140.

dos Santos, F., Andre, L., Casper, P. (2000). Different methods for extracting bacteria from freshwater sediment and a simple method to measure bacterial production in sediment samples. Journal of microbiological methods, 41(3): 249-257.

Geetha, S., Muddula Krishna, N., Rushinadha Rao Kakara, G.R.V., Ramesh Babu, K. (2016) Microbial assessment of commercially important crabs from Visakhapatnam fishing harbour, east coast of India. European Journal of Experimental Biology 6(4): 57-61.

Hamiroune M. A., Saoudi, K.K., Foughalia, A. (2020). Bacteriological study of the farmed mussel (Mytilus galloprovincialis) and its impact on public health. Agricultura, 115-116 (3-4): 158-167.

Harrigan, F.W., Mccance, M.E. (1976) Laboratory Methods in Food and Dairy Microbiology, Academic Press, London, U.K.

Ikhwanuddin, M. (2020) Portunid crab breeding and larval rearing, paving the way for sustainable aquaculture. Pakistan Journal of Biological Sciences 23(12): 1500-1505.

Krieg, N.R., Holt, J.G. (1984) Bergey's Manual of Systematic Bacteriology. Vol. 1 William and Wilkins Baltinore, London, U.K.

Lawal-Are, A.O. (2010) Reproductive Biology of the Blue Crab, Callinectes amnicola in the Lagos Lagoon, Nigeria. Turkish Journal of Fish and Aquatic Science 10:1-7.

Lawal-Are, A.O., Kusemiju, K. (2000) Size composition, growth pattern and feeding habits of the blue crab, Callinectes amnicola (De Rocheburne) in the Badagry Lagoon, Nigeria.
Journal of Scientific Research and Development 4:117-126.

Moruf, R.O, Saba, A.O., Chukwu-Osazuwa, J., Elegbede, I.O. (2019) Seasonal variation in macro-micronutrient compositions of the flesh and shell of the portunid crab, Callinectes amnicola (De Rochebrune, 1883) from the coastal waters of Southwest Nigeria. Agricultura 102 (1-2): 200-209.

Moruf, R.O., Adekoya, K.O. (2020) Genetic heterogeneity of portunid crab populations from three interconnecting topical lagoons. Polish Journal of Natural Sciences 35(3): 301-311.

Moruf, R.O., Lawal-Are, A.O. (2017a). Size composition, growth pattern and condition factor of two portunid crabs, Callinectes amnicola (De Rochebrune) and Portunus validus (Herklots) off Lagos coast, Nigeria. Nigerian Journal of Fisheries and Aquaculture 5(1): $15-21$.

Moruf, R.O., Lawal-Are, A.O. (2017b) Comparability in dietary elements, sex ratio and fecundity of portunidae crabs Callinectes amnicola (De Rochebrune) and Portunus validus (Herklots) off Lagos coast, Nigeria. Journal of Aquatic sciences 32(1A): 25-31.

Nayak, S.K. (2010) Role of gastrointestinal microbiota in fish. Aquaculture Research 41(11): 1553-1573.

Okon, M., AKinjogunla, O., Akang, I. A., Akaka, B. C., Umoh, M. (2020) Logarithmic and percentage reductions of bacterial isolates in Galatea paradoxa treated with Citrus aurantifolia and Nacl: Public health implication and nutritional assessment. Fudma journal of sciences 4(3): 406-415.

Oranusi, S., Effiong, E.D., Duru, N.U. (2018) Comparative study of microbial, proximate and heavy metal compositions of some gastropods, bivalve and crustacean seafood. African Journal of Clinical and Experimental Microbiology 19(4): 291-302.

Saxena, G., Bharagava, R. N., Kaithwas, G., \& Raj, A. (2015). Microbial indicators, pathogens and methods for their monitoring in water environment. Journal of water and Health, 13(2): $319-339$.

Uaboi-Egbenni, P.O., Okolie, P.N., Famuyiwa, O., Teniola, O. (2010) The significance of pathogenic bacteria in the gut of swimming crab, Callinectes sp. obtained from Lagos lagoon and market samples stored at freezer temperature $\left(0^{\circ}\right.$ C). Pakistan Journal of Nutrition 9(4): 398-403. 